\title{
Sub-Soil Properties of Hydrocarbon Contaminated Sites in Parts of the Eastern Niger Delta, Nigeria
}

\author{
Nwankwoala, H.0, Mzaga, T.M \\ Department of Geology, University of Port Harcourt, Nigeria. \\ nwankwoala_ho@yahoo.com
}

\begin{abstract}
This study aims at assessing the subsurface soil properties of contaminated sites in parts of the Niger Delta with a view to providing basic data that would guide not only future development and construction in the region but in choosing remediation options for contaminated sites. Standard soil sampling and analytical methods were employed in the study. Soil moisture content values range from 5.2 to 97.9 with spikes at Okrika OKR-CTRL and BM-CTRL probably due to shallow water table encountered at shallow depth of $2.0 \mathrm{~m}$. While the average moisture level at contaminated sites was 20.08 while that of the control sites was 17.85 . The variation also suggests higher water retention potential of contaminated soils against normal clean soil which in essence will enhance contaminant persistence in the soil. The soil $\mathrm{pH}$ value for control sites tends to normal range i.e towards 7.0, while the values for impacted sites are slightly lower. Most samples had normal soil pH ranges except BM-SS1 which indicated acidic soil conditions with ranges of 4.5-5.8. Liquid Limit is higher for control samples than contaminated sites at Okrika, Ogu-Bolo, Bomu manifold and Norkpo while Liquid Limit value for impacted site at Sime is higher than the control site and similar for Nonwa sites. This variation could be as a result of the impact of the contamination on the soil. The plastic limit is highest at BM-SS, OGB-SSOKR-SSNOR-SS and lowest at SIM-CTRL, NOW-CTRL, NOW-SS, OGB-CTRL and BM-CTRL. Generally hydrocarbon contamination decreases liquid limit, plastic limit and Plasticity index of the soil. There is a generally slight reduction in porosity values at the impacted sites as compared with the control sites. The soil profile across the study area grade from fine silty sands to fine gravel sand and the soil profile up to depth of investigation were generally dominated by silts, sands and sandy clay in different proportions. Following this, stoppage of infiltration of liquid hydrocarbon product and movement of contaminated water through it will continue unhindered.
\end{abstract}

Keywords: Soil contamination, hydrocarbon, soil properties, boreholes, groundwater

\section{INTRODUCTION}

There has been extensive oil contamination of swamp, rivers, creeks and groundwater in Ogoniland, Rivers State, Nigeria as a result of hydrocarbon exploration (Ofoma et al., 2008; UNEP 2011; Olof and Jonas, 2013; Giadom \& Tse, 2014). The contamination levels were high enough to cause significantly severe effects on human health and the ecosystem (Osuji \& Iruka, 2006; Osuji \& Opiah, 2007; Nwankwoala et al., 2013). It is reported that surface waters had extractable petroleum hydrocarbons (EPHs) ( $>10-C 40)$ concentration of up to $7420 \mu \mathrm{g} / \mathrm{l}$, found in drinking water wells and $9000 \mu \mathrm{g} / \mathrm{l}$ benzene in groundwater (Nwankwoala \& Mzaga, 2017). These values are 900 times higher than the WHO guidelines of 2009. Sediments had as high as $17,900 \mathrm{mg} \mathrm{kg}^{-1}$ EPH concentrations with Polycyclic aromatic hydrocarbons concentrations values recording $8.0 \mathrm{mg} \mathrm{kg}^{-1}$, in most of the samples analysed. The UNEP (2011) assessment reported that the effects of the contamination have destroyed mangrove areas. Climatic conditions are favourable for natural degradation of petroleum hydrocarbon contaminants however continuous re-pollution has prevented quick environmental regeneration (Atlas, 1981; Clay 2014).

Effective determination of contaminated sites can only be achieved with adequate knowledge of the interplay of site specific factors such as geology, nature of the contaminant, pathway receptors linkages, toxicity levels and 
Sub-Soil Properties of Hydrocarbon Contaminated Sites in Parts of the Eastern Niger Delta, Nigeria

deployment of appropriate contamination management techniques and legislation (Akpokodje, 1987; Edward et al., 1992; Shekwolo \& Igbuku, 2014; Abam, 2016).

The challenge of development to poor soil conditions, a situation which has escalated project cost and as a consequence impeded development (NDES, 1995; EGASPIN, 2002). The understanding the interplay of the geomorphology, geology and the engineering behavior of the soils in the region is critical (Maletic et al., 2011; Kermani \& Ebadi, 2012; Shittu, 2014). The slow physical development of the Niger delta region has been a major reason for youth restiveness, with its ramified impacts on crude oil production levels, security, employment, etc. This study therefore investigates the geotechnical behavior of soils.

\section{The Study Area}

The study area lies in the coastal Niger Delta sedimentary basin. The geology of the Niger Delta has been described in details by various authors. The formation of the Delta started during Early Paleocene and resulted mainly from the buildup of fine grained sediments eroded and transported by the River Niger and its tributaries. The Tertiary Niger Delta is a sedimentary structure formed as a complex regressive offlap sequence of clastic sediments ranging in thickness from 9,000-I2, 000m. Starting as separate depocenters, the Niger Delta has coalesced to form a single united system since Miocene. The Niger Delta is a large and ecologically sensitive region, in which various water species including surface and sub-surface water bodies exist in a state of dynamic equilibrium (Abam, 2016). The Niger Delta has spread across a number of ecological zones comprising sandy coastal barriers, brackish or saline mangrove, freshwater and seasonal swamp forests. The Niger Delta consists of three diachronous units, namely Akata (oldest), Agbada and Benin (youngest) formations. The Benin Formation (Oligocene to Recent) is about $2100 \mathrm{~m}$ thick at the basin centre and consists of medium to coarse grained sandstones, thin shales and gravels (Weber and Dakouru, 1975).

The hydrogeology of the area at different times has described the Benin Formation as a highest yeilding water bearing zone of the area (Etu-Efeotor, 1981). Overlying the $40 \mathrm{~m}-150 \mathrm{~m}$ thick Quaternary deposits, the Benin Formation consists of sequences of sands and silty clay alternating which later become increasingly prominent seawards (Etu-Efeotor and Akpokodje, 1990). Based on strata logs in the area, described the aquifer in the area as a stack of alternating aquifers lying upon each other in a multiple fashion such that the uppermost ones are mostly unconfined and underlain by the confined aquifers (Amadi et al., 1989).

The Niger Delta has two most important aquifers, Deltaic and Benin Formations. With a typically dendritic drainage network, this highly permeable sands of the Benin Formation allows easy infiltration of water to recharge the shallow aquifers. Nwankwoala et al., 2013 described the aquifers in this area as a set of multiple aquifer systems stacked on each other with the unconfined upper aquifers occurring at the top. Recharge to aquifers is direct from infiltration of rainfall, the annual total of which varies between $5000 \mathrm{~mm}$ at the coast to about $2540 \mathrm{~mm}$ landwards. Groundwater in the area occurs in shallow aquifers of predominantly continental deposits encountered at depths of between $45 \mathrm{~m}$ and $60 \mathrm{~m}$. The lithology comprises a mixture of sand in a fining up sequence, gravel and clay. Well yield is excellent, with production rates of 20,000 litres/hour common and borehole success rate is usually high (Etu-Efeotor and Odigi 1983). Across the area, measures transmissivity varies from 59 to $6050 \mathrm{~m}^{2} / \mathrm{d}$, Hydraulic conductivity from 0.04 to $60 \mathrm{~m} / \mathrm{d}$ and storage coefficient from $10^{-6}$ to 0.15 (Amadi et al., 2012). Surface water occurrence includes numerous networks of streams, creeks and rivers.

Groundwater recharge system in the study area is sourced from direct precipitation with an annual intensity of as high as $2000-2400 \mathrm{~mm}$. Water permeates the Benin formation sands to recharge the aquifers. The multilayer aquifer system has shallow unconfined aquifers at the upper limit of the geologic units providing most of the domestic water needs of the communities' inhabitants (Nwankwoala et al., 2013). The water table in the area is between $0.7 \mathrm{~m}$ to $3.5 \mathrm{~m}$ depth and fluctuates with the prevailing land profile and season (UNEP, 2011; SPDC, 2013). These aquifers are therefore vulnerable to pollution from a range of contaminants ranging from, 
hydrocarbon contaminant plumes, solid wastes and leachates (Gawdziki \& Ygadlo, 1990; Hughes et al., 2003; USEPA, 2009).

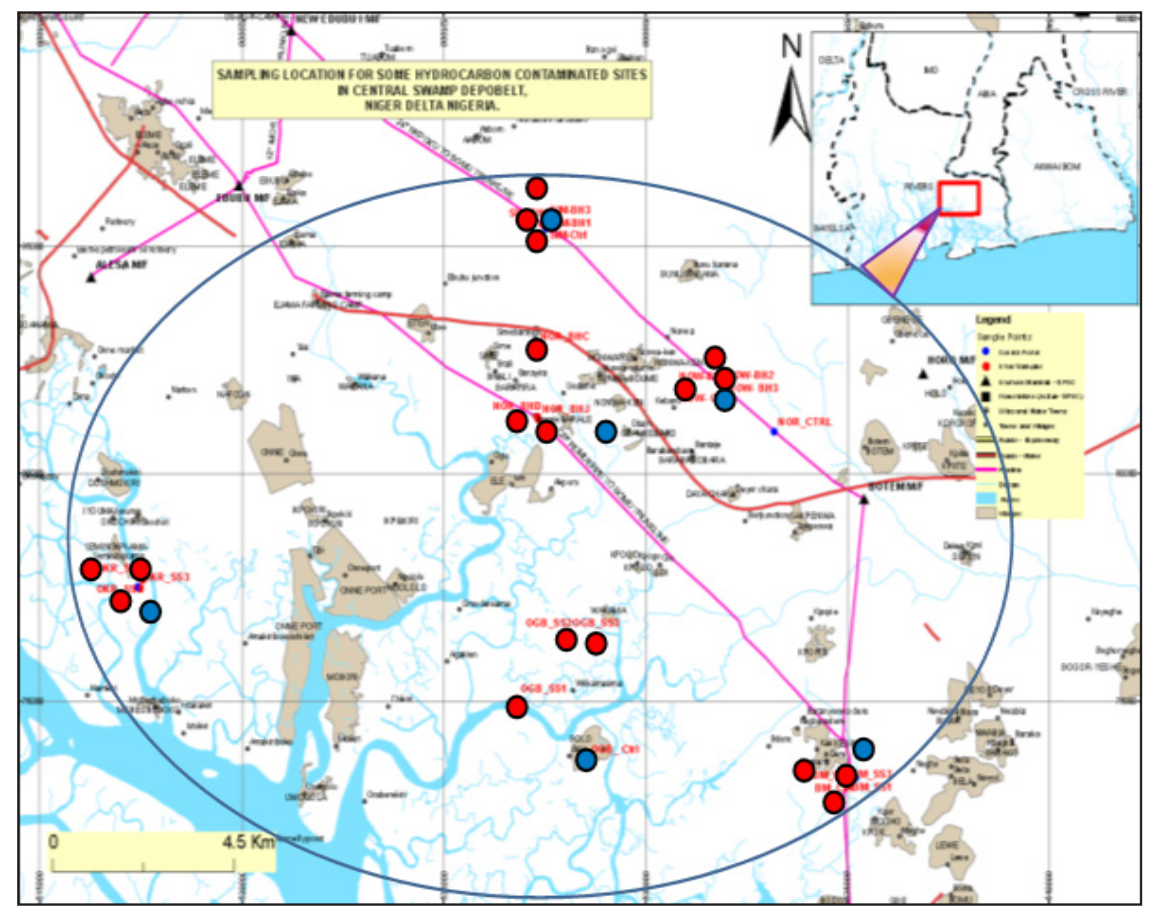

Figure1. Location map of Study Area showing sample locations

\section{Materials ANd Methods}

Location and sample point positions were gotten with use of a hand held Global Positioning System device (GPS). Soil samples were collected from hand augered holes at depths of $1 \mathrm{~m}, 2 \mathrm{~m}$, and $3 \mathrm{~m}$. Soil samples were duplicated while the National and international standards and methods were used during sample analyses using competent personnel and the right equipment and materials. The geographical position of the sample point is established and read off using a GPS device and recorded. Discrete Soil Samples were collected using the grab method with aid of a hand auger and water samples were also collected from boreholes drilled using percussion drilling methods. The investigation comprised drilling of 4 boreholes by cable percussion, recovered of samples and borehole logging.

\section{Cable Percussion Boreholes}

Four (4) Cable percussion boreholes were designed e.g NOW-BH1, NOW-BH2, NOW-BH3 and NOW-CTR for drilling at the 4 locations - Nonwa, Sime, Norkpo and Bomu sites respectively to depths of $10 \mathrm{~m}$ below existing ground level (bgl). Standard cable percussion boring equipment was used to produce $150 \mathrm{~mm}$ diameter boreholes. Clean drilling techniques were employed at the sites, including the use of casing made the ground and any contaminated underlying strata in each borehole in order to avoid cross-contamination. Detailed records of the cable percussion boreholes have been produced in accordance with national and international standards. Details of the borehole installations were provided on the respective borehole records as appropriate.

\section{Geotechnical Samples}

Samples for geotechnical analysis were collected in aluminium plates. This was done to ensure the integrity of the samples. The device uses an exclusive two-probe measuring system which allows both probes to be inserted 
into the same depth in the soil and allows the metals to be exposed to the same amount of soil providing the most effective way to consistently and properly measure soil $\mathrm{pH}$. The $\mathrm{pH}$ was then read on the calibration and recorded. The $\mathrm{pH}$ and moisture meters are made of sensitive tips with and sampling devices were washed with sterilized water after each measurement.

The Moisture Meter is a Brass soil moisture probe with an eight inch metal stem and Meter with $0-10$ calibrations mounted on top. The probe has a sensor at the tip and penetrates to root level. The moisture reading is then indicated is read off at the tip of the pointer needle and recorded. The analytical procedures adopted for the various parameters are APHA methods.

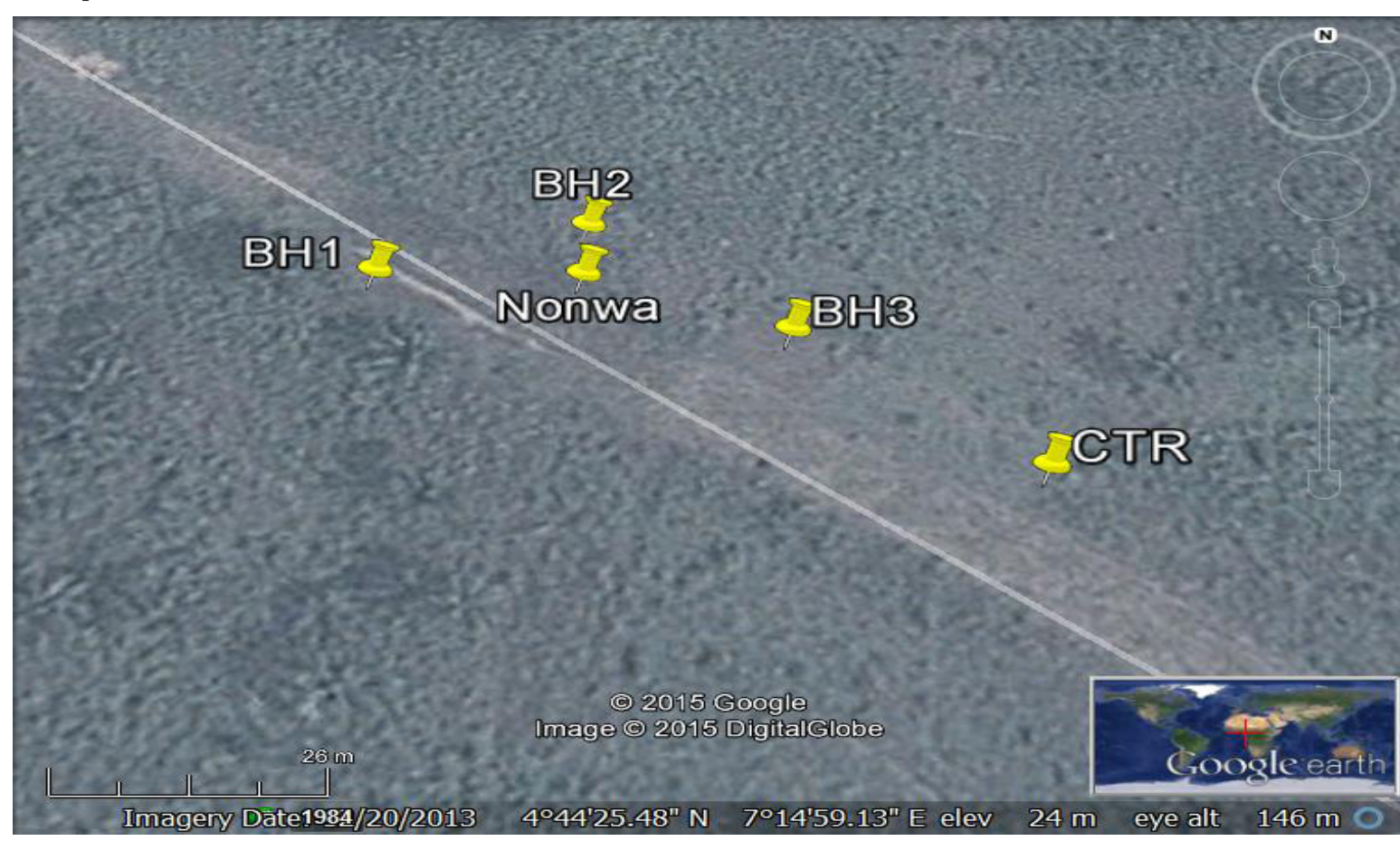

Figure2. Typical Google map showing sampling point locations

Table1.Geotechnical Parameters and Procedures of Analysis

\begin{tabular}{|c|c|}
\hline Test Parameter & Procedure BS 1377 (1990) \\
\hline Moisture Content & Part 2 section 2.2 \\
\hline Grain size analysis & Part 2 section 9.3 \\
\hline Atterberg limits & ASTM D4318 \\
\hline Liquid Limit & ASTM D4318 \\
\hline Plastic Limit & ASTM D4318 \\
\hline Plasticity Index & ALLEN HAZEN \\
\hline Permeability & - \\
\hline Porosity & \\
\hline
\end{tabular}


Sub-Soil Properties of Hydrocarbon Contaminated Sites in Parts of the Eastern Niger Delta, Nigeria

\section{RESULTS AND DISCUSSION}

Table2. Results of Physical Parameters

\begin{tabular}{|c|c|c|c|c|c|c|c|c|c|c|}
\hline \multicolumn{11}{|c|}{ Table 2: Summary of On-site Parametres } \\
\hline \multirow[t]{3}{*}{ Site Name } & \multirow[t]{3}{*}{ Sample ID } & \multicolumn{2}{|c|}{ GPS Coordinates } & \multirow[t]{3}{*}{ Elevation } & \multicolumn{6}{|c|}{ In-situ Parameters } \\
\hline & & \multirow{2}{*}{$\begin{array}{l}\text { Northing } \\
\text { Latitude }\end{array}$} & \multirow{2}{*}{$\begin{array}{c}\text { Easting } \\
\text { Longitude }\end{array}$} & & \multicolumn{3}{|c|}{ moisture Content } & \multicolumn{3}{|c|}{$p H$} \\
\hline & & & & & $1 m$ & $2 m$ & $3 m$ & $1 m$ & $2 m$ & $3 m$ \\
\hline \multirow{4}{*}{$\begin{array}{c}\text { Bomu } \\
\text { Manifold }\end{array}$} & BM_SS1 & 4.66294 & 7.27788 & $20.70 \mathrm{~m}$ & $\mid 18.67$ & 18.7 & 29.21 & 4.6 & 4.5 & 5.8 \\
\hline & BM_SS2 & 4.661526 & 7.277251 & $15.60 \mathrm{~m}$ & 25.04 & 15.19 & 21.32 & 6.6 & 6.55 & 6 \\
\hline & BM_SS3 & 4.661585 & 7.2777208 & $17.90 \mathrm{~m}$ & 28.04 & 29.88 & 17.12 & 6.65 & 6 & 6.45 \\
\hline & BM_CTRL & 4.66294 & 7.279345 & $17.60 \mathrm{~m}$ & 15.2 & 72.9 & NS & 7 & 6.3 & NS \\
\hline \multirow[b]{4}{*}{ Ogu-Bolo } & OGB_SS1 & 4.67842 & 7.20369 & $10.80 \mathrm{~m}$ & 19.6 & 18.7 & 29.21 & 6.65 & 6.6 & 5.8 \\
\hline & OGB_SS2 & 4.691593 & 7.215291 & $15.50 \mathrm{~m}$ & 25.04 & 15.19 & 21.32 & 6.55 & 6.55 & 6 \\
\hline & OGB_SS3 & 4.691618 & 7.2153 & $15.50 \mathrm{~m}$ & 28.04 & 29.88 & 17.12 & 6.56 & 6 & 6.45 \\
\hline & OGB_Control & 4.66636 & 7.219411 & $6.60 \mathrm{~m}$ & 5.2 & 6.4 & 6.8 & 6.8 & 6.7 & 6.5 \\
\hline \multirow[b]{4}{*}{ Okrika } & OKR_SS1 & 4.702188 & 7.119898 & $12.70 \mathrm{~m}$ & 18.67 & 18.7 & 29.21 & 6.6 & 6.6 & 5.8 \\
\hline & OKR_SS2 & 4.702108 & 7.119892 & $0.70 \mathrm{~m}$ & 25.04 & 15.19 & 21.32 & 6.5 & 6.55 & 6 \\
\hline & OKR_SS3 & 4.700406 & 7.11932 & $6.90 \mathrm{~m}$ & 28.04 & 29.88 & 17.12 & 6.65 & 6 & 6.45 \\
\hline & OKR_CTRL & 4.70048 & 7.11891 & $9.50 \mathrm{~m}$ & 15.2 & 97.9 & NS & 6.2 & 6.9 & NS \\
\hline \multirow[b]{4}{*}{ Nonwa } & NOW-BH1 & $04^{0} 44^{\prime} 26.2^{\prime \prime}$ & $007^{0} 14^{\prime} 57.8^{\prime \prime}$ & $23.116 \mathrm{~m}$ & 18.6 & 17.7 & 25.21 & 6.55 & 6.3 & 5.8 \\
\hline & NOW-BH2 & $04^{0} 44^{\prime} 26.5^{\prime \prime}$ & $007^{0} 14^{\prime} 58.6^{\prime \prime}$ & $23.338 \mathrm{~m}$ & 23.04 & 12.19 & 19.32 & 6.55 & 6.55 & 6 \\
\hline & NOW- BH3 & $04^{0} 44^{\prime} 25.9^{\prime \prime}$ & $007^{0} 14^{\prime} 59.4^{\prime \prime}$ & $23.333 \mathrm{~m}$ & 25.04 & 25.88 & 15.12 & 6.3 & 6.2 & 6.55 \\
\hline & NOW-BH- CTRL & $04^{0} 44^{\prime} 25.2^{\prime \prime}$ & $007^{0} 15^{\prime} 00.3^{\prime \prime}$ & $23.741 \mathrm{~m}$ & 9.2 & 8.4 & 7.8 & 6.9 & 6.7 & 6.3 \\
\hline \multirow[b]{4}{*}{ Norkpo } & NOR_BHC & $04^{0} 44^{\prime} 53.9^{\prime \prime}$ & $007^{0} 12^{\prime} 28.8^{\prime \prime}$ & 9.7 & 18.67 & 16.7 & 19.21 & 6.3 & 6.2 & 5.9 \\
\hline & NOR_BHD & $04^{0} 44^{\prime} 04.1^{\prime \prime}$ & $007^{0} 12^{\prime} 29.0^{\prime \prime}$ & 9.91 & 15.04 & 17.19 & 9.32 & 8.5 & 6.55 & 6 \\
\hline & NOR_BHJ & $04^{0} 44^{\prime} 02.8^{\prime \prime}$ & $007^{0} 12^{\prime} 30.3^{\prime \prime}$ & 9.626 & 18.04 & 17.88 & 17.12 & 6.65 & 6 & 6.45 \\
\hline & NOR_CTRL & $04^{0} 43^{\prime \prime} 53.9^{\prime \prime}$ & $007^{0} 15^{\prime \prime} 40.1^{\prime \prime}$ & 6.282 & 9.2 & 10.9 & 12.2 & 6.2 & 6.9 & 6.42 \\
\hline \multirow[b]{4}{*}{ Sime } & SIM-BH1 & 85436.476 & 527554.503 & 21.577 & 15.04 & 16.7 & 16.21 & 6.9 & 6.9 & 6.9 \\
\hline & SIM-BH2 & 85487.044 & 527445.476 & 21.39 & 15.04 & 17.19 & 13.32 & 7 & 7 & 6.9 \\
\hline & SIM-BH3 & 85566.108 & 527542.41 & 21.671 & 16.04 & 17.88 & 15.12 & 6.7 & 7 & 6.8 \\
\hline & SIM-CTRL & 85390.119 & 527536.538 & 21.984 & 15.2 & 14.9 & 13.2 & 6.8 & 6.9 & 6.9 \\
\hline
\end{tabular}


Sub-Soil Properties of Hydrocarbon Contaminated Sites in Parts of the Eastern Niger Delta, Nigeria

Table3. Summary Results for Geotechnical Parameters

\begin{tabular}{|c|c|c|c|c|c|c|}
\hline \multirow[t]{3}{*}{ Site Name } & \multirow[t]{3}{*}{ Sample ID } & \multirow{2}{*}{\multicolumn{5}{|c|}{ Summary Result for Geotechnical Parameters }} \\
\hline & & & & & & \\
\hline & & Permeability k x $10-4(\mathrm{~m} / \mathrm{sec})$ & Porosity \% & LL & PL & PI \\
\hline \multirow[b]{2}{*}{ Bomu Mfd } & BM-SS & 1.36 & 0.33 & 27 & 20 & 7 \\
\hline & BM-CTRL & 1.69 & 0.43 & 38 & 23 & 16 \\
\hline \multirow[b]{2}{*}{ Ogu-Bolo } & OGB-SS & 1.45 & 0.35 & 28 & 28 & 7 \\
\hline & OGB-CTRL & 1.16 & 0.44 & 41 & 22 & 21 \\
\hline \multirow[b]{2}{*}{ Okrika } & OKR-SS & 1.60 & 0.35 & 35 & 25 & 10 \\
\hline & OKR-CTRL & 1.45 & 0.43 & 38 & 23 & 16 \\
\hline \multirow[b]{2}{*}{ Nonwa } & NOW-SS & 1.38 & 0.36 & 26 & 16 & 13 \\
\hline & NOW-CTRL & 1.23 & 0.20 & 26 & 14 & 12 \\
\hline \multirow[b]{2}{*}{ Norkpo } & NOR-SS & 1.43 & 0.35 & 27 & 14 & 13 \\
\hline & NOR-CTRL & 1.54 & 0.40 & 36 & 19 & 17 \\
\hline \multirow[b]{2}{*}{ Sime } & SIM-BH3 & 1.58 & 0.20 & 22 & 12 & 10 \\
\hline & SIM-CTRL & 2.00 & 0.43 & 21 & 11 & 10 \\
\hline
\end{tabular}

(Note: CTRL= Control Samples)

\section{DisCUSSION OF RESULTS}

\section{Soil Profile}

The soil profile across the study area grade from fine silty sands to fine gravel sand. The soil mixtures were as varied across the sites. However, the soil profile up to depth of investigation is generally dominated by silts, sands and sandy clay in different proportions. This kind of soil will not be able to stop infiltration of liquid hydrocarbon product and movement of contaminated water through it will continue unhindered.

\section{Soil Properties}

Hydrocarbon products when released to the environment are hazardous to the ecosystems (Nwankwoala \& Mzaga, 2017). Although it is naturally insoluble in water, it can infiltrate the soil and contaminate the groundwater. Some of the trapped hydrocarbons clog within the voids and pore spaces, making it difficult and costly to remove. These chemicals degrade the soil engineering properties and hence distort the soil behaviours. The controlling factors for soil-water system behaviour is controlled by (i) the quantity and type clay mineral (ii) nature of pore fluid, (iii) associated anions and cations (iv) organic matter. Almost all soil Properties are affected by Soil-waste interactions basically due to ion exchange or nature of pore fluid. However, it is better to consider the effects of the pollutants independently for better understanding owing to the complex nature of the effects. The effects may differ based on soil type. Pollutants have different effect on different clayey soils and these pollutants are considered based on index properties and Permeability. Atterberg limits, permeability and porosity will be discussed based on their role in contaminant transport and persistence in contaminated media 


\section{Soil Moisture Content}

Soil moisture content values range from 5.2 to 97.9 with spikes at Okrika OKR-CTRL and BM-CTRL probably due to shallow water table encountered at shallow depth of $2.0 \mathrm{~m}$. While the average moisture level at contaminated sites was 20.08 while that of the control sites was 17.85 . This slight difference in moisture could have resulted from the introduction of the fourth phase on the soil structure which possible gave rise to more water molecules adhering unto the soil grains and in effect creating an atmosphere for chemical reactions to take place in the soil. The variation also suggests higher water retention potential of contaminated soils against normal clean soil which in essence will enhance contaminant persistence in the soil. Table 2 and Figure 3 show the variation of moisture across various sites and depths.

\section{Soil pH}

Soil acidity or alkalinity is measured using a pH scale. The device is calibrated on $0-14$ mangitude, with 7 as the midpoint or normal. The smaller the values indicate higher levels of acidity while higher values i.e above 7, indicates increasing alkaline conditions (Table 4 and Figure 4). Bioremediation processes are significantly affected by Soil pH levels just like soil properties (physical, biological and chemical) and processes. Reduced microbial activities in contaminated soil for instance imply persistence of hydrocarbon contaminants in such soil (Wang et al., 2013). Low pH leads to decrease in nutrition, growth, and yields of most crops. These factors improve as optimum $\mathrm{pH}$ levels are restored. Optimal $\mathrm{pH}$ range is between 5.5 and 7.0. Some plant however can adapt to $\mathrm{pH}$ ranges outside of the normal range. As shown in Figure 4 the soil $\mathrm{pH}$ values for control sites tends to normal range i.e towards 7.0 while the values for impacted sites are slightly lower.

Most samples had normal soil pH ranges except BM-SS1 which indicated acidic soil conditions with ranges of 4.5-5.8. Formation of acid soils can be due to any of several processes which may include use of fertilizer, activity of plant root, rainfall and the weathering of soil minerals etc. At a petroleum impacted site as observed BH-SS (Figure 4), pH readings tend to strong acidity probably due to history of prolonged hydrocarbon contamination (Zihms, et al., 2013). Small changes in pH values can induce severe changes in the sensitive biochemical environment thereby altering biological and chemical processes.

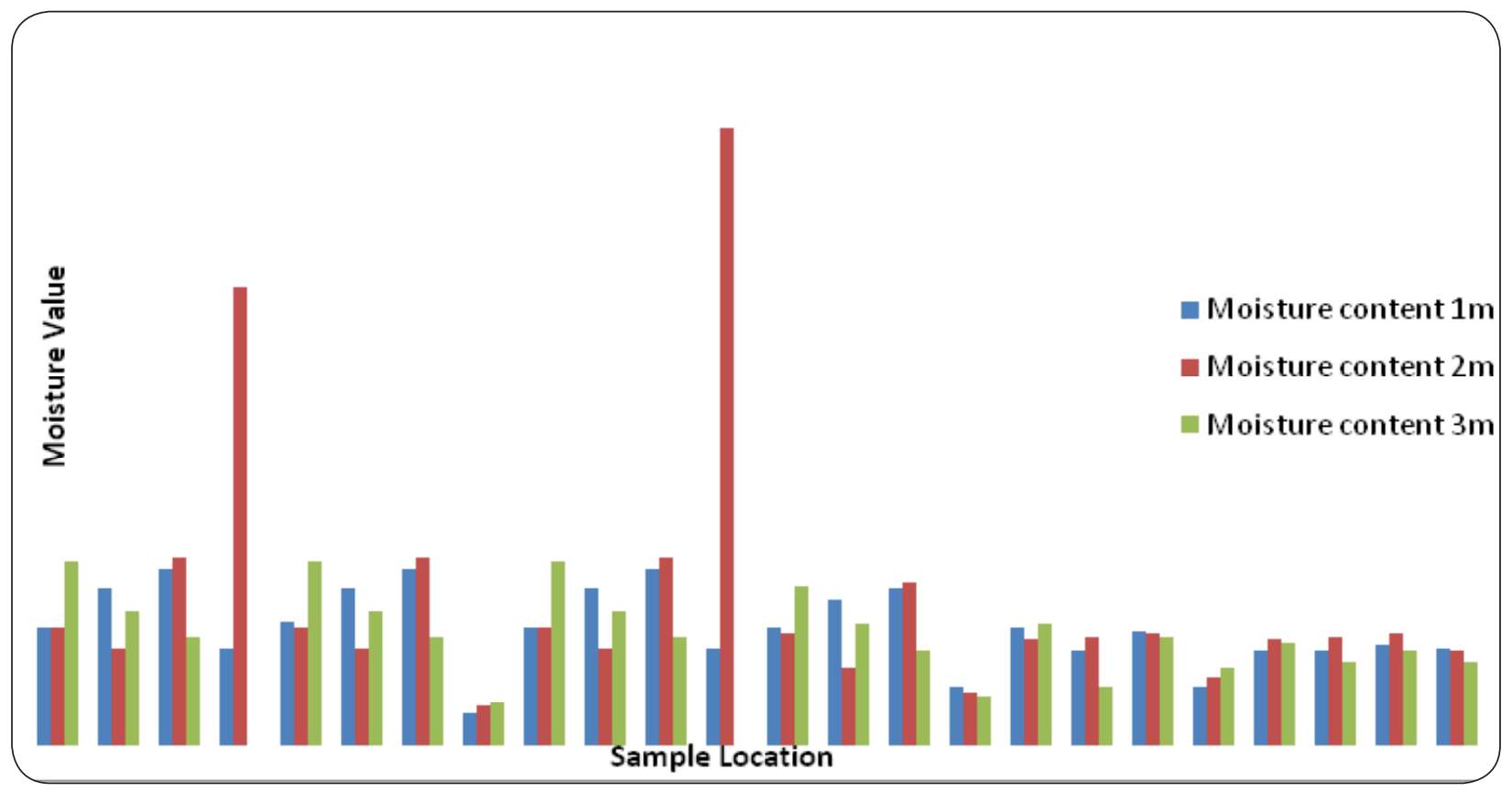

Figure3. Histogram of In-situ Soil Moisture Across Various Sites and Depths 


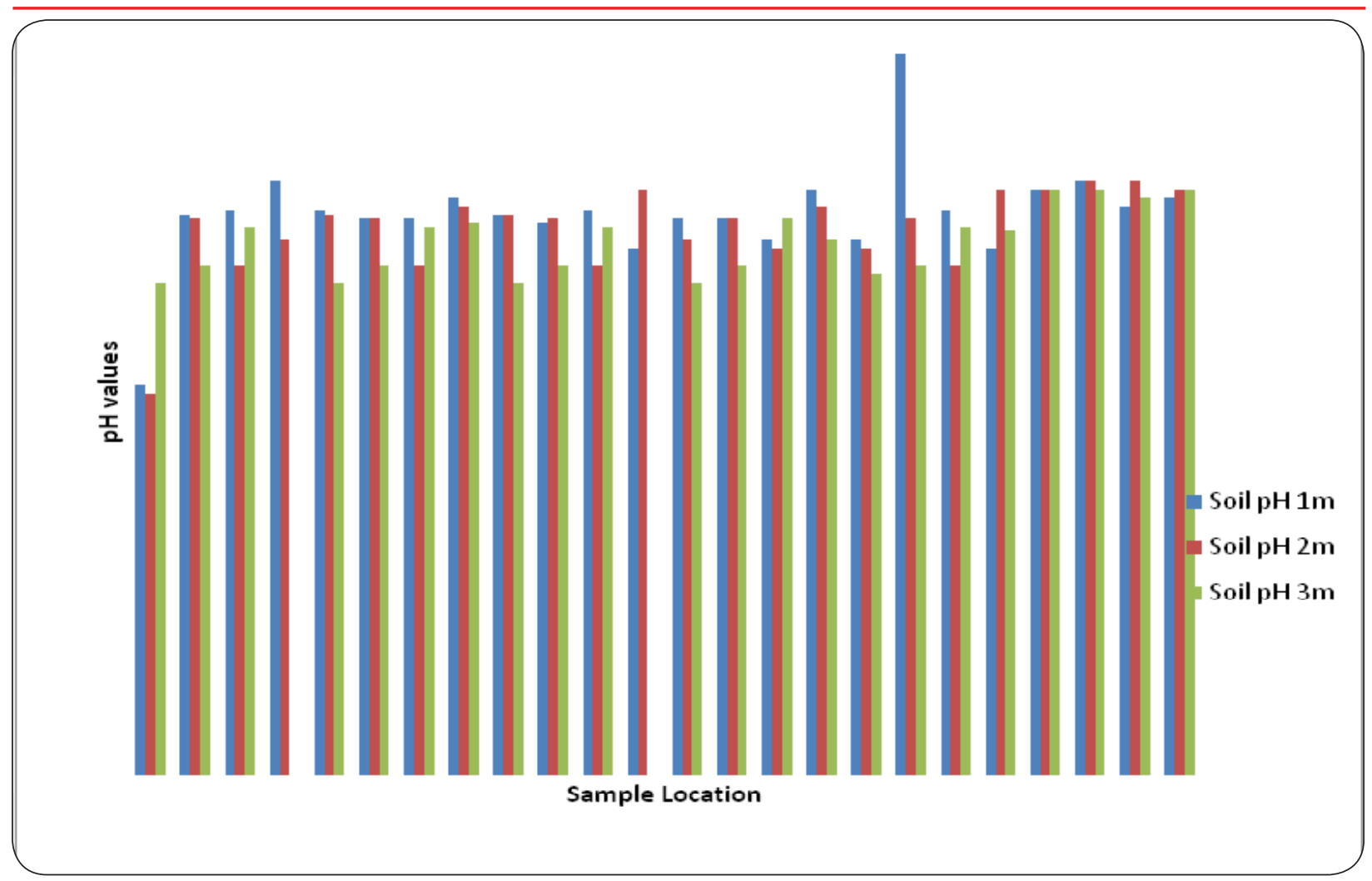

Figure4. Histogram of Soil pH variation across the various sample points

Table4. Soil pH Classification Range (Source:Torstensson et al., 1998)

\begin{tabular}{|c|c|}
\hline Description & pH Range \\
\hline Ultra Acidity & Less than 3.5 \\
\hline Extreme Acidity & 3.5 to 4.4 \\
\hline Very strong acidity & 4.5 to 5.0 \\
\hline Strongly acidity & 5.1 to 5.5 \\
\hline Moderate acidity & 5.6 to 6.0 \\
\hline Slight acidity & 6.1 to 6.5 \\
\hline Normal (neutral) & 6.6 to 7.3 \\
\hline Slight alkalinity & 7.4 to 7.8 \\
\hline Moderate alkalinity & 7.9 to 8.4 \\
\hline Strong alkalinity & 8.5 to 9.0 \\
\hline Very strong alkalinity & $>9.0$ \\
\hline
\end{tabular}




\section{Atterberg Limits}

As shown in Figure 5, the general reduction in the Atterberg Limits values for the contaminated sites compared with the values at control sites. This is most likely the result of the soil degradation due to contamination at the sites. Liquid Limit is higher for control samples than contaminated sites at Okrika, Ogu-Bolo, Bomu manifold and Norkpo while Liquid Limit value for impacted site at Sime is higher than the control site and similar for Nonwa sites. This variation could be as a result of the impact of the contamination on the soil. It implies that the impacted soil have less ability to hold water than the clean soil, the flow and movement of contaminants in impacted soil will therefore be easier and faster than clean soil. The plastic limit is highest at BM-SS, OGB-SSOKR-SSNOR-SS and lowest at SIM-CTRL, NOW-CTRL, NOW-SS, OGB-CTRL and BM-CTRL. Generally hydrocarbon contamination decreases liquid limit, plastic limit and Plasticity index of the soil.

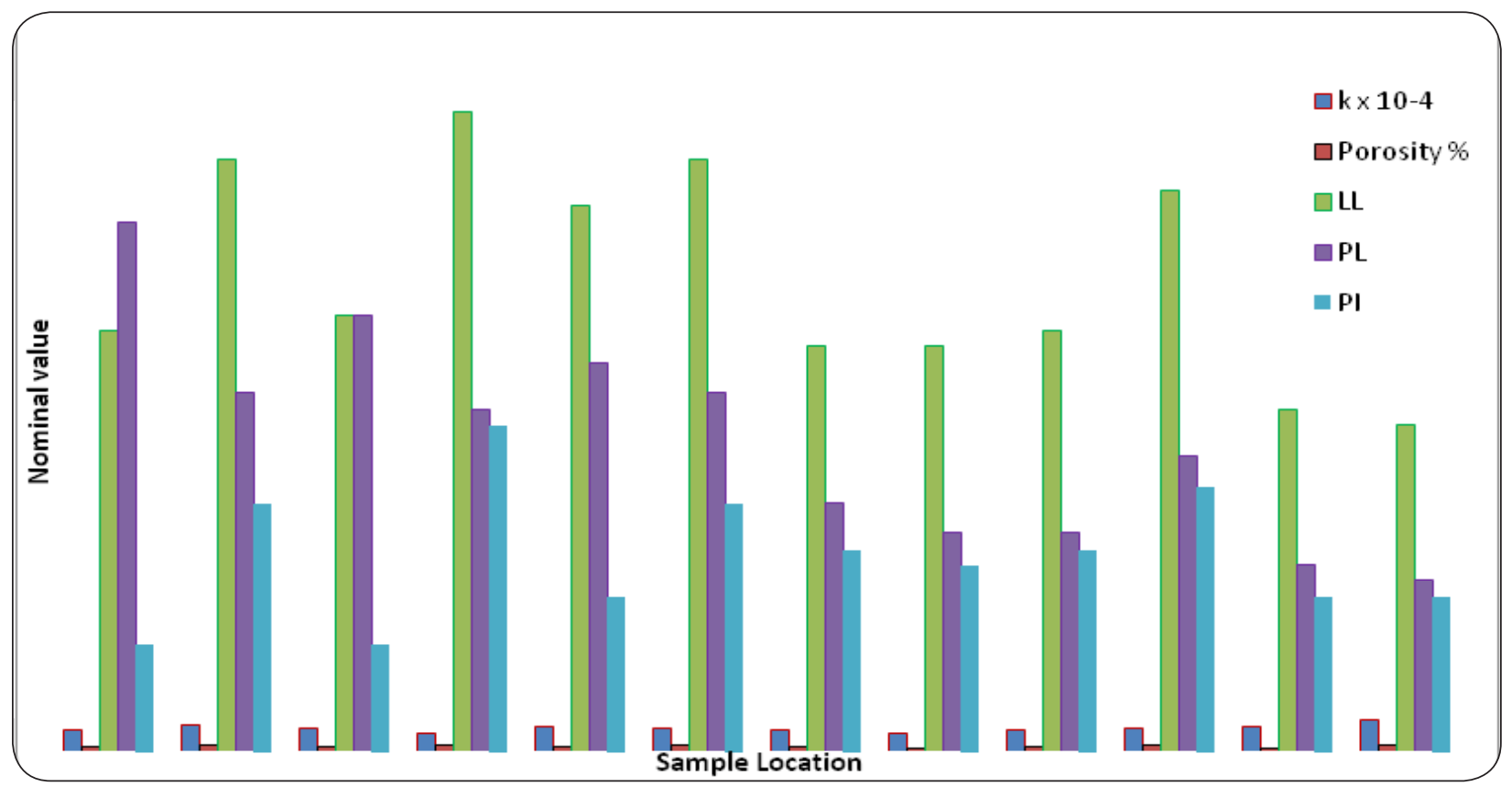

Figure5. Histogram of Soil Permeability, Porosity and Consistency Chart

\section{Porosity}

From Figure 5, Porosities and permeability values at impacted sites are generally lower than control sites. Permeability at BM-SS is lower than BM-CTRL, and may be as a result of the much soil agitation due to ongoing remediation works at the time of the investigation. The impacted sections of the site have suffered some distortions and so is the soil profile. There is a generally slight reduction in porosity values at the impacted sites as shown in Figure 5 compared with the control sites. These reductions may be attributed the effects of the crude oil contamination. The control sites BM-CTRL, OKR-CTRL, NOR-CTRL and SIM-CTRL showed higher permeability values than impacted sites. These changes in soil characteristics have the capability of determining the behaviour of contaminants in the soil.

\section{Particle Size Distribution}

The grain sizes of soils in the area are poorly graded, from fine sands of $0.07 \mathrm{~mm}$ sieve sizes to fine gravel sizes of $4 \mathrm{~mm}$ sieve sizes. (Figures 6 - 8). This grading is typical of beach sands. The grain distribution increases as one moves towards the sea from Norkpo to Okrika indicating that the ease of contaminant infiltration into the subsurface will as well increase in that order owing to increasing permeability of the soil. 
Sub-Soil Properties of Hydrocarbon Contaminated Sites in Parts of the Eastern Niger Delta, Nigeria

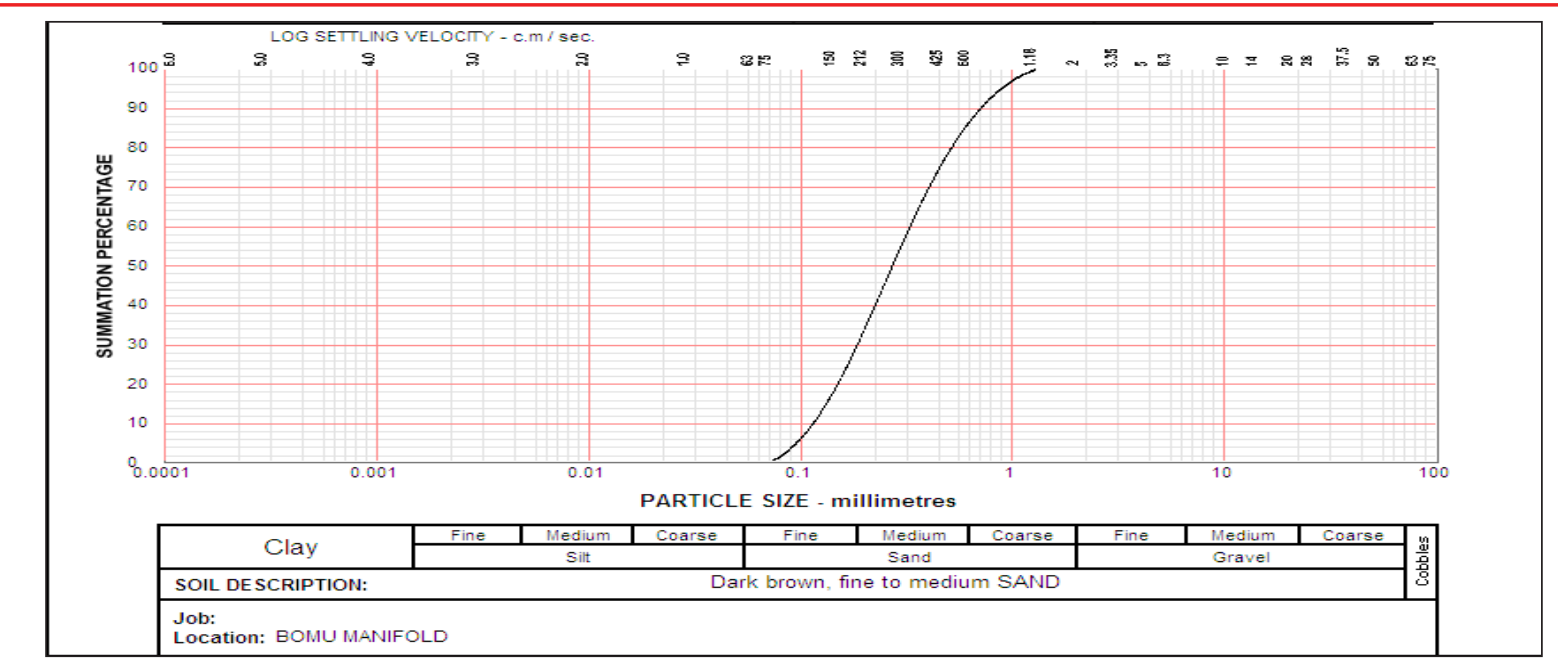

Figures6. SoilParticle Size Distribution for Bomu Manifold

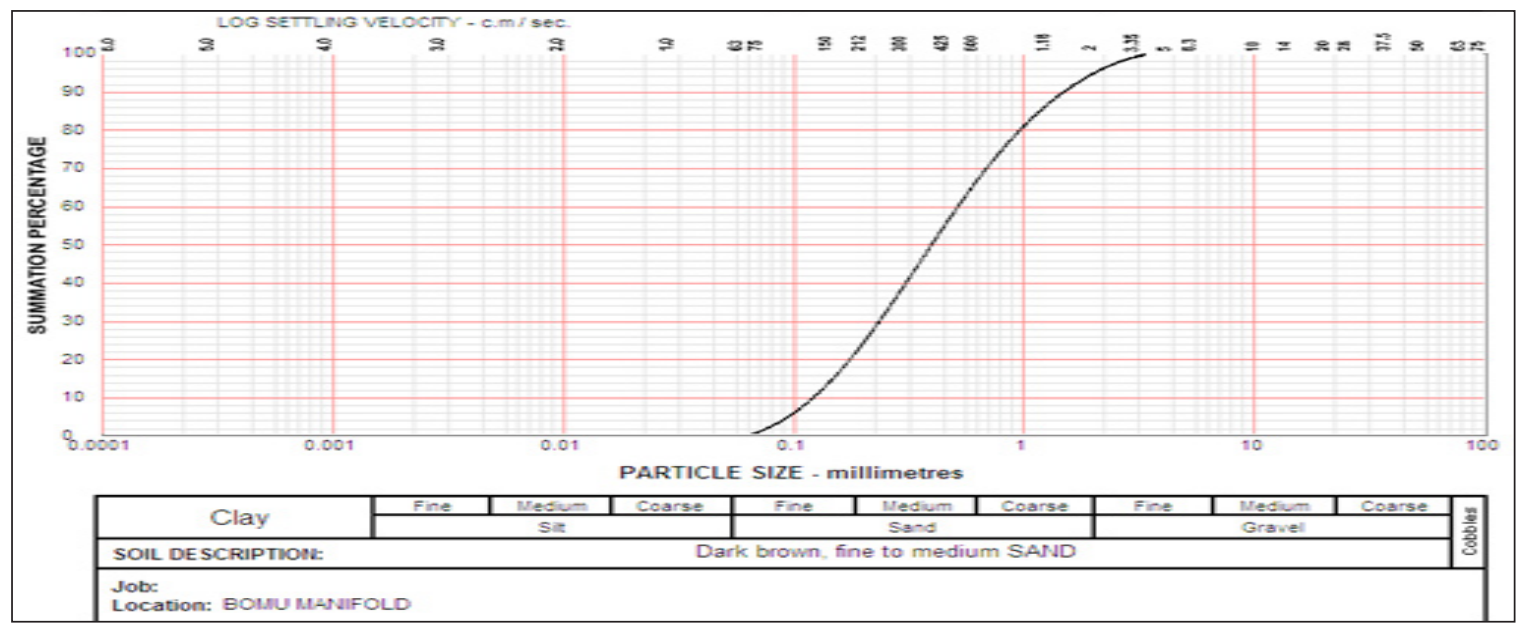

Figure7. SoilParticle Size Distribution for Bomu Manifold

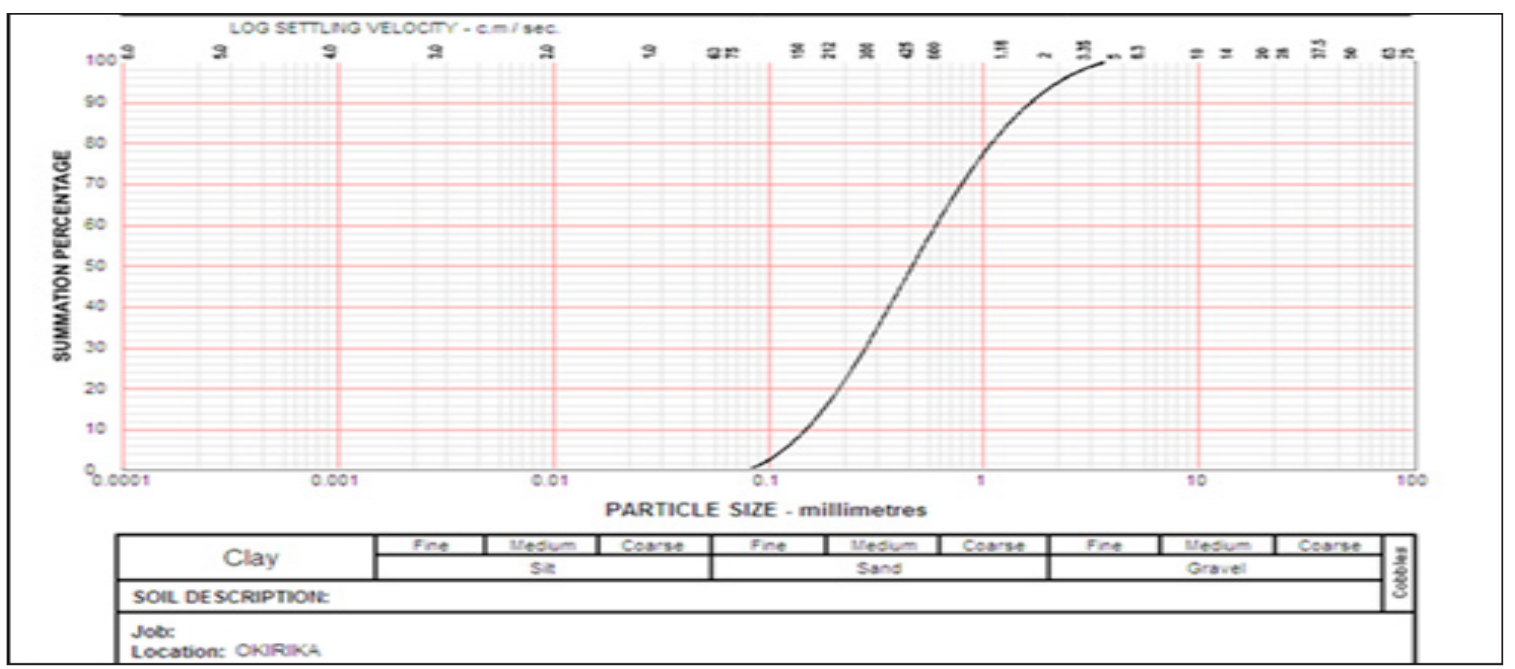

Figure8. Soil Particle Size Distribution for Okrika 
Sub-Soil Properties of Hydrocarbon Contaminated Sites in Parts of the Eastern Niger Delta, Nigeria

Atterberg (Consistency) Limits

The Atterberg Limits are generally lower in the impacted samples as shown in figure 5. Liquid limit values for impacted soils range from 22-35 and control sites values fall between 21-41; Plastic limit is 12-28 for impacted and 11- 23 for control, Plasticity index is 7-13 for impacted and 10-16 for control sites. This is an indication of alteration due to the presence of contaminants in the impacted samples.

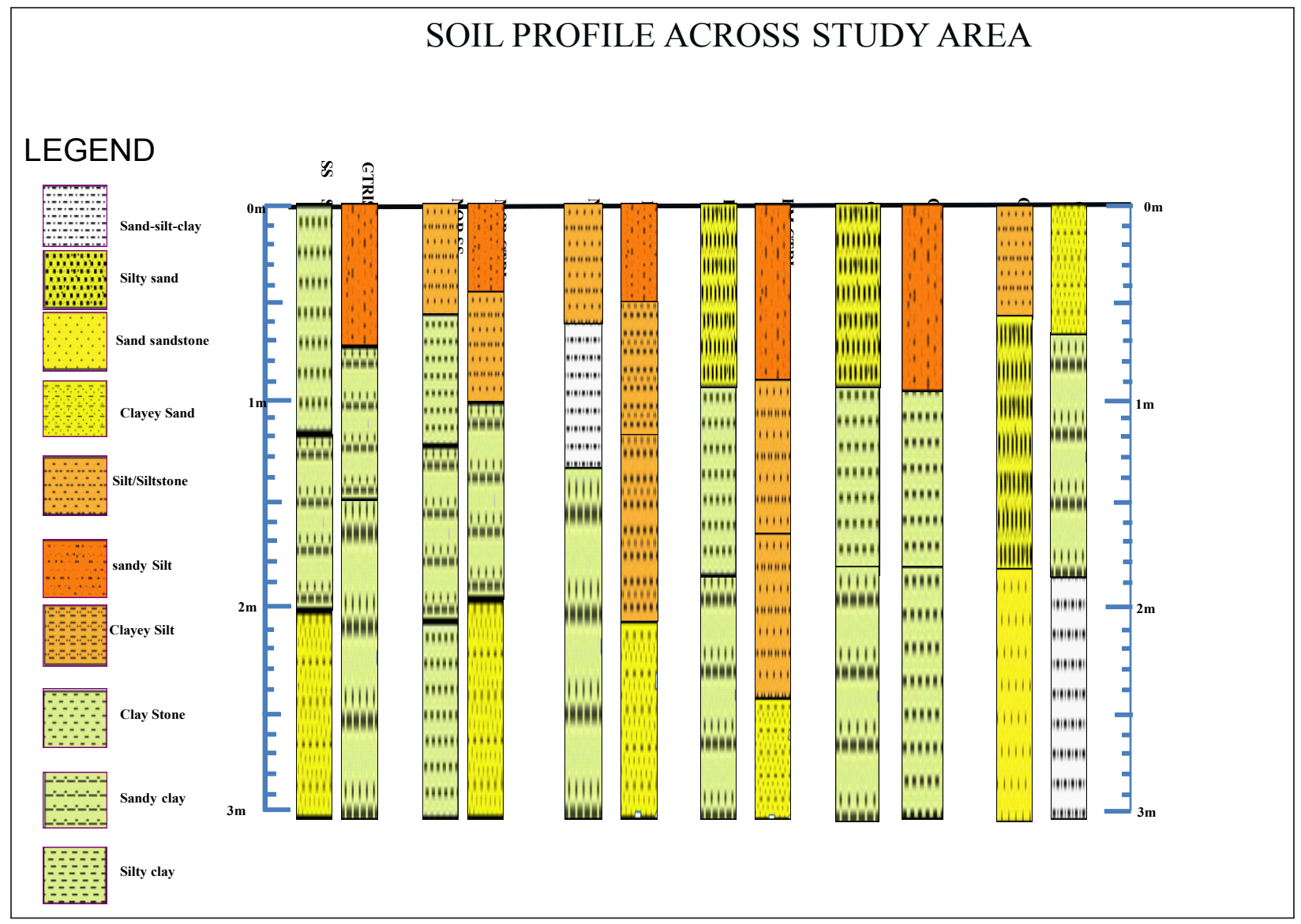

Figure9. Soil Profile in the Study Area

\section{CONCLUSION}

This study revealed that the soil moisture content values range from 5.2 to 97.9 with spikes at Okrika OKRCTRL and BM-CTRL probably due to shallow water table encountered at shallow depth of $2.0 \mathrm{~m}$. This slight difference in moisture could have resulted from the introduction of the fourth phase on the soil structure which possible gave rise to more water molecules adhering unto the soil grains and in effect creating an atmosphere for chemical reactions to take place in the soil. Most samples had normal soil pH ranges except BM-SS1 which indicated acidic soil conditions with ranges of 4.5-5.8.

At a petroleum impacted site as observed BH-SS, pH readings tend to strong acidity probably due to history of prolonged hydrocarbon contamination at the site. Liquid Limit is higher for control samples than contaminated sites at Okrika, Ogu-Bolo, Bomu manifold and Norkpo while Liquid Limit value for impacted site at Sime is higher than the control site and similar for Nonwa sites. This variation could be as a result of the impact of the contamination on the soil. 
Sub-Soil Properties of Hydrocarbon Contaminated Sites in Parts of the Eastern Niger Delta, Nigeria

The plastic limit is highest at BM-SS, OGB-SSOKR-SSNOR-SS and lowest at SIM-CTRL, NOW-CTRL, NOW-SS, OGBCTRL and BM-CTRL. Generally hydrocarbon contamination decreases liquid limit, plastic limit and Plasticity index of the soil. There is a generally slight reduction in porosity values at the impacted sites as compared with the control sites. The grain sizes of soils in the area are poorly graded, from fine sands of $0.07 \mathrm{~mm}$ sieve sizes to fine gravel sizes of $4 \mathrm{~mm}$ sieve sizes. The soil profile across the study area grade from fine silty sands to fine gravel sand. The soil mixtures were as varied across the sites. However, the soil profile up to depth of investigation is generally dominated by silts, sands and sandy clay in different proportions. This kind of soil will not be able to stop infiltration of liquid hydrocarbon product and movement of contaminated water through it will continue unhindered. Regular soil monitoring is recommended.

\section{REFERENCES}

1. Abam,T.K.S (2016). Engineering Geology of the Niger Delta. Journal of Earth Sciences and Geotechnical Engineering, 6(3): 65-89

2. Akpokodje E.G., (1987). The engineering-geological characteristics and classification of the major superficial soils of the Niger Delta. Engineering Geology 23:193-211

3. Amadi, A. N., Olasehinde, P. I., Yisa J., Okosun, E. A., Nwankwoala, H. O., Alkali Y. B.,(2012). Geostatistical Assessment of Groundwater Quality from Coastal Aquifers of Eastern Niger Delta, Nigeria. Journal of Geosciences. 2(3): 51-59

4. Amadi, P.A, Morrison, T. and Ofoegbu, C.O., (1989). Hydrogeochemical assessment of groundwater quality in parts of the Niger Delta, Nigeria. Environmental Geology and Water Science. 14(3):195-202.

5. Atlas, R. M.,(1981). Microbial degradation of petroleum hydrocarbons: an environmental Perspective. Microbiological Review, 45(1):180 - 189.

6. Clay, S.L., (2014). Fate of petroleum hydrocarbons in the environment. Unpublished MSc Dissertation submitted to McMaster University, School of Geography and Earth Sciences. Available online at https:// macsphere.mcmaster.ca

7. Edward J. Calabrese, Paul T. Kostecki., (1992). Principles and Practices for Petroleum Contaminated Soils. 2:245-257. Lewis Publishers. Available online @ https://books.google.co.uk

8. EGASPIN (2002). Environmental Guidelines and Standards for the Petroleum Industry in Nigeria.Issued by the Department of Petroleum Resources. Lagos, Revised Edition.

9. Etu-Efeotor, J. O and Odigi M. T. (1983). Water Supply Problems in the eastern Niger Delta, Bulletin Nigeria Mining and Geoscience Association. 20:183-1992.

10. Etu-Efeotor, J.O and Akpokodje, E.G (1990). Aquifer systems of the Niger Delta. Journal of Mining Geology, 26 (2): 279-284.

11. Etu-Efeotor, J.O., (1981).Preliminary Hydrogeochemical investigations of Sub-Surface waters in parts of the Niger Delta. Nigerian Journal of Mining Geology; 18(1): 103-105

12. Fingas, M., (2000). The Basics of Oil Spill Cleanup. 2nd ed. London, New York Washington Dc: Lewis Publishers. Available online @ https://books.google.kz/books

13. Gawdziki,J and Ygadło, M., (1990.) Modelling Transport of Hydrocarbons in Soil-Water Environment. Ecological Chemistry and Engineering. 3(17): 12 - 23. Available online at https://www.researchgate.net

14. Giadom, F.D and Tse,A.C., (2014). Groundwater Contamination and Environmental Risk Assessment of a 
Sub-Soil Properties of Hydrocarbon Contaminated Sites in Parts of the Eastern Niger Delta, Nigeria

Hydrocarbon Contaminated Site in Eastern Niger Delta, Nigeria. Journal of Environment and Earth Sciences.5 (14): 123 - 133.

15. Hughes, L., G. Lethbridge, F. Mahmoud, V. Paul, C. G. Shelton (2003). Framework for risk management of historically contaminated land for SPDC operations in the Niger Delta mangrove and other swamp areas, Shell Global Solutions (UK), HSE Consultancy

16. Kermani, M. and Ebadi, T., (2012). The effect of oil contamination on the geotechnical properties of finegrained soils. International Journal of Soil and Sediment Contamination. 21(5):655-671. Available online @ https://www.researchgate.net

17. Maletić,S.P; . Dalmacija, B.D;. Roncevic, S.D; Agbaba, J.R and Perovic, S.D.U (2011). Impact of hydrocarbon type, concentration and weathering on its biodegradability in soil. Journal of Environmental Science and Health, Part A(46) : 1042-1049

18. Ngah, S.A and Nwankwoala, H.O., (2013). Evaluation of Geotechnical Properties of the Sub-soil for Shallow Foundation Design in Onne, Rivers State, Nigeria. The Journal of Engineering and Science, 2 (11): 08-16.

19. Nwankwoala H.O, Marshal, H.I and Oborie, E., (2013). Characterization and Quantitative Indicators of Groundwater Quality in Okrika, Rivers State, Nigeria International Journal of Science Inventions today. (3):319-334. Available online at www.ijsit.com

20. Nwankwoala HO, Mzaga TM (2017). Geo-Environmental Assessment of Hydrocarbon Contaminated Sites in Parts of Central Swamp Depobelt, Eastern Niger Delta. MOJ Eco Environ Sci 2(3): 00023. DOI: 10.15406/ mojes.2017.02.00023

21. Olof, L and Jonas P (2013;) Oil Contamination in Ogoniland. Journal AMBIO, 42(6):685-701 Niger Delta Available online @ www.ncbi.nlm.nih.gov

22. Osuji L.C and Iruka N., (2006). An appraisal of the impact of petroleum hydrocarbons on soil fertility: The Owaza experience . African Journal of Agricultural research. 2(7):318-324. Available online @ http://www. academicjournals.org

23. Osuji, L.C, and Opiah, U (2007). Hydrocarbon contamination of a terrestrial ecosystem: the case of Oshire-2 oil spill in Niger Delta, Nigeria. The Environmentalist 27(3):337-340

24. Shekwolo P.D and Igbuku A.A., (2014). Integrated Remediation Techniques in handling complex crude oil impacted site at Ejama Ebubu - Niger Delta, Nigeria. Presentation at the 21st International Petroleum Environmental Conference in Houston, Texas. Available online @ ipec.utulsa.edu

25. Shell Petroleum Development Company limited (SPDC) (2013). Oil Spill Response and Remediation Management Standards (OSRRMS).

26. Shittu W. J (2014) Mapping oil spill human health risk in Rivers state, Niger Delta, Nigeria. Unpublished Dissertation submitted to the University of Nottingham for the degree of doctor of philosophy

27. Short KC, Stauble AJ., (1967). Outline geology of the Niger Delta. American Association of Geologists, 51(5):761-779. Available online @ https://books.google.com/

28. Torstensson, L., Pell, M. and Stenberg, B. (1998). Need of a strategy for evaluation of arable soil quality. Journal of Human Environment. 27(1): 4-8.

29. United Nations Environmental Program., (2011). Environmental Assessment of Ogoniland . Available online @ www.unep.org/ 
Sub-Soil Properties of Hydrocarbon Contaminated Sites in Parts of the Eastern Niger Delta, Nigeria

30. Wang, Y.,Jiang, F., Qianxin, L., Xianguo, L., Wang, X., Guoping, W. (2013). Effects of crude oil contamination on soil physical and chemical properties in Momoge wetland of China . Chinese Geographical Science. 23(6):708-715. Aavailable @ link.springer.com

31. Weber, K.J., and Daukoru, E.M. (1975). Petroleum geology of the Niger delta: 9th World Petroleum Congress Proceedings. 2:209-221

32. Zihms, S.G., Switzer C., Karstunen, M., Tarantino, A. (2013) Understanding the effects of high temperatures on the engineering properties of soil : Lessons to share from smouldering remediation experience. Flamma, 6(1):5-7. Available online @ www.issmge.org.

Citation: Nwankwoala, H.O, Mzaga, T.M, "Sub-Soil Properties of Hydrocarbon Contaminated Sites in Parts of the Eastern Niger Delta, Nigeria", American Research Journal of Earth Science, vol 1, no. 1, pp. 80-93.

Copyright (C) Nwankwoala, H.O, Mzaga, T.M, This is an open access article distributed under the Creative Commons Attribution License, which permits unrestricted use, distribution, and reproduction in any medium, provided the original work is properly cited. 